\title{
Louis Pierre Gratiolet (1815-1865) and His Contribution to the Study of Cerebral Convolutions in Primates
}

\author{
André Parent \\ Département de Psychiatrie et de Neurosciences, Faculté de Médecine, Université Laval, Québec City, \\ Canada \\ Email: Andre.Parent@fmed.ulaval.ca
}

Received 22 December 2013; revised 20 January 2014; accepted 18 February 2014

Copyright (C) 2014 by author and Scientific Research Publishing Inc.

This work is licensed under the Creative Commons Attribution International License (CC BY). http://creativecommons.org/licenses/by/4.0/

(c) (7) Open Access

\begin{abstract}
Louis Pierre Gratiolet (1815-1865) was one of the first modern anatomists to pay attention to cerebral convolutions. Born in Sainte-Foy-la-Grande (Gironde), he moved to Paris in 1834 to study medicine, as well as comparative anatomy under Henri de Blainville (1777-1850). In 1842, he accepted de Blainville's offer to become his assistant at the Muséum d'histoire naturelle and progressively abandoned medicine for comparative anatomy. He undertook a detailed study of brains of human and nonhuman primates and soon realized that the organizational pattern of cerebral convolutions was so predictable that it could serve as a criterion to classify primate groups. He noted that only the deepest sulci exist in lower primate forms, while the complexity of cortical folding increases markedly in great apes and humans. Gratiolet provided the first cogent description of the lobular organization of primate cerebral hemispheres. He saw the insula as a central lobe around which revolved the frontal, parietal, temporal (temporo-sphenoidal) and occipital lobes. He correctly identified most gyri and sulci on all brain surfaces, introduced the term "plis de passage" for some interconnecting gyri, and provided the first description of the optic radiations. In the early 1860s, Gratiolet fought a highly publicized battle against Paul Broca (1824-1880) on the relationship between brain and intelligence. Gratiolet agreed that the brain was most likely the seat of intelligence, but he considered human cognition far too subtle to have any direct relationship with brain size. He argued that a detailed study of the human brain architecture would be more profitable than Broca's vain speculations on the relationship between brain weight and intelligence, which he considered a monolithic entity. Despite remarkable scientific achievements and a unique teaching capacity, Gratiolet was unable to secure any academic position until three years before his sudden death in Paris at age 49.
\end{abstract}


Keywords

Humans; Primates; Cerebral Hemispheres; Cerebral Convolutions; Cerebral Cortex; Neuroscience History

\section{Introduction}

The cerebral cortex is a relatively recent phylogenetic acquisition that reaches its highest level of complexity in human and nonhuman primates. The human cerebral cortex has a total area of approximately $2200 \mathrm{~cm}^{2}$ and a volume of about 500,000 $\mathrm{mm}^{3}$; it harbors around $20-30$ billion neurons that are engaged in roughly $3 \times 10^{14}$ morphologically differentiated inter-neuronal contacts [1]. This astonishing figure corresponds to the number of milliseconds that have elapsed in the last 10,000 years, that is, since the beginning of the Neolithic period [2]. The cerebral cortex forms the most voluminous portion of the human brain, but only one third of it is readily visible, the remaining part being hidden in the depths of sulci [1]. Surprisingly, cortical sulci and gyri attracted little attention until the $19^{\text {th }}$ century, when clinical neurology, neuropathology and comparative anatomy start to unveil the complexity and functional significance of the cortical mantle. This assay is devoted to the Louis Pierre Gratiolet, who was one of the first anatomists to systematically exploit the comparative approach as a tool to map the cortical surface in primates.

\section{A Short Biography}

Louis Pierre Gratiolet (Figure 1) was born in 1815 in Sainte-Foy-la-Grande (Gironde), a small city that saw also the birth of Paul Broca (1824-1880), another famous brain anatomist. Gratiolet's father was a medical doctor who practiced first at Sainte-Foy and then at Bordeaux, where the young Louis Pierre started his college studies. Early in the 1830s, Gratiolet moved to Paris, where he entered the medical school. During his internship at la Salpêtrière, Gratiolet's dedication towards anatomy worth him the support of the chief physician, the celebrated Etienne Parsiset (1770-1847). While at la Salpêtrière, Gratiolet assiduously followed the learned comparative anatomy lectures of Henri-Marie Ducrotay de Blainville (1777-1850), at the nearby Muséum d'histoire naturelle. In 1842, he accepted de Blainville's offer to become his assistant at the Muséum and progressively abandoned medicine for comparative anatomy. Gratiolet worked during two decades at the Muséum, first as a laboratory assistant, then as a part-time lecturer (1844-1850), and finally as Head of the anatomical study section (1853-1862) [3]. The year 1854 was a landmark in Gratiolet's career and personal life. Early that year, he published his first major work on the anatomy of primate brains, and later he married Madeleine Schloesing, who gave him three children, two boys (Pierre and Ludovic) and one girl (Aline). While at the Muséum, Gratiolet did not confine

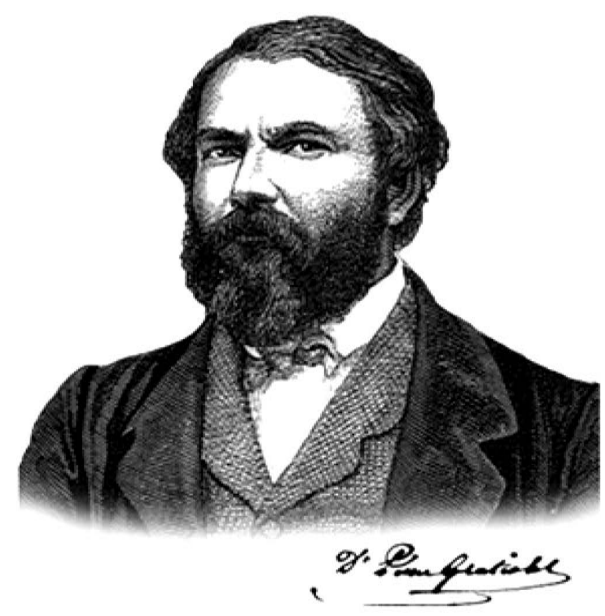

Figure 1. Louis Pierre Gratiolet, a portrait that served as a frontispiece for Broca’s eulogy [3]. 
himself to the study of cerebral convolutions; he actively investigated the microscopic organization of the spinal cord, the embryological development of various brain structures, such as the cerebellum, certain aspects of brain pathology and the comparative anatomy of animals as varied as the leech and the hippopotamus. He devoted the later part of his career to the study of mechanisms of facial expression and the anthropological aspects brain-intelligence relationship [3]. In 1858, the French government awarded him the title of Chevalier de la Légion d'honneur. However, despite his remarkable scientific achievement and a unique teaching capacity, Gratiolet faced great difficulties in his attempt to secure an academic position so that he had to raise his small family in very difficult conditions. It is only late in 1863 that Gratiolet was asked to officially replace Isidore Geoffroy Saint-Hilaire (1805-1861) as professor of Zoology at the Faculty of science of the University of Paris, a position that allowed him to teach at la Sorbonne. Unfortunately, he did not enjoy this prestigious and well-deserved chair for long as he died from a massive stroke early in 1865 at age 49.

\section{Earlier Views of Cortical Folds and Fissures}

The Greek anatomist Erasistratus (c. 310-350 BC) was probably the first to draw attention to the organizational complexity of cortical folds and fissures in various species. This Alexandrian physician went as far as to relate the degree of prominence of cortical convolutions to that of intelligence. However, three centuries later, the influential physician Galen (c. 129-201) bluntly rejected this view. For him, the cortical folds did not deserve more attention than the coils of the small intestine (enteroid processes). Galen believed that higher brain functions had their seat deep within the cerebral ventricles, not on the surface of the brain. Rekindled by Christian philosophy, this view progressively became a dogma that dominated medical thought for more than 1500 years [4]. Things started to change in the middle of the 17th century when Franciscus de le Boë Sylvius (1614-1672), a learned brain anatomist who worked at Leyden, noted in the human brain a deep lateral fissure that "divides the cerebrum into an upper, larger part and a lower, smaller part" [5], a fissure to which Sylvius' name is still attached. Later in the century, the Oxford physician Thomas Willis (1621-1675) detected a certain regularity in the pattern of organization of cortical convolutions in various mammals. He noted that these brain folds are much less abundant in quadrupeds than in humans and are much more extended in primates than in carnivores. However, Willis's depiction of the cerebral cortex is astonishingly sketchy (Figure 2) by comparison to his rather accurate rendition of the subcortical structures, particularly the corpus striatum [6] [7]. In the 18th century, the French physician and anatomist Félix Vicq d'Azyr (1748-1794) went a step further by recognizing that, while less numerous than in humans, the cortical convolutions in monkeys were bilaterally symmetric and similarly organized in all individuals belonging to the same genus [8]. Surprisingly, however, Vicq d'Azyr thought that the structural pattern of human cortical gyri and sulci varied significantly from one side of the brain to the other, as well as from one individual to the other. Vicq d'Azyr appears to have been the first to delineate the central sulcus, but he did not name it (Figure 3(a)). It is the French anatomist and alienist François Leuret (1797-1851) who, having apparently misread Vicq d'Azyr's work, associated the name of the Italian anatomist Luigi Rolando (1773-1831) to the central sulcus (Figure 3(c)) [4]. A renewal of interest in brain convolutions occurred early in the $19^{\text {th }}$ century, when Franz-Joseph Gall (1758-1828) formulated his localisation theory [9]. Gall argued that all major human faculties are located in specific regions of the cortical mantle, but his insistence on the simple palpation of the skull (cranioscopy) as a means to determine the relative prominence of each of these cortical loci led to the rapid collapse of his system (phrenology) [4]. In 1829, the Italian neuroanatomist Luigi Rolando provided what appears to be the first accurate rendering of the human brain convolutions [10]. Yet, despite the faithfulness of his description and the clarity of his illustrations (Figure 3(b)), Rolando's work went relatively ignored until Gratiolet rediscovered it and made it the foundation of his own work.

\section{A Major Contribution to Brain Anatomy}

Following the path traced by de Blainville, Gratiolet progressively became one of the leading comparative neuroanatomists of the $19^{\text {th }}$ century. Except for a brief account of a case of microcephaly, he did not pay much attention to pathological anatomy nor did he use vivisection to determine the functional correlates of brains structures. Yet, Gratiolet can be considered a pioneer in the study of the embryological development of the brain, as well as in the microscopic analysis of neuronal tissue. His careful microscopic examination of the human spinal cord allowed him to provide a fairly adequate description of the major spinal cord fiber bundles, together with realistic depictions of spinal neurons, with their multiple protoplasmic extensions (dendrites) and unique cylinder- 


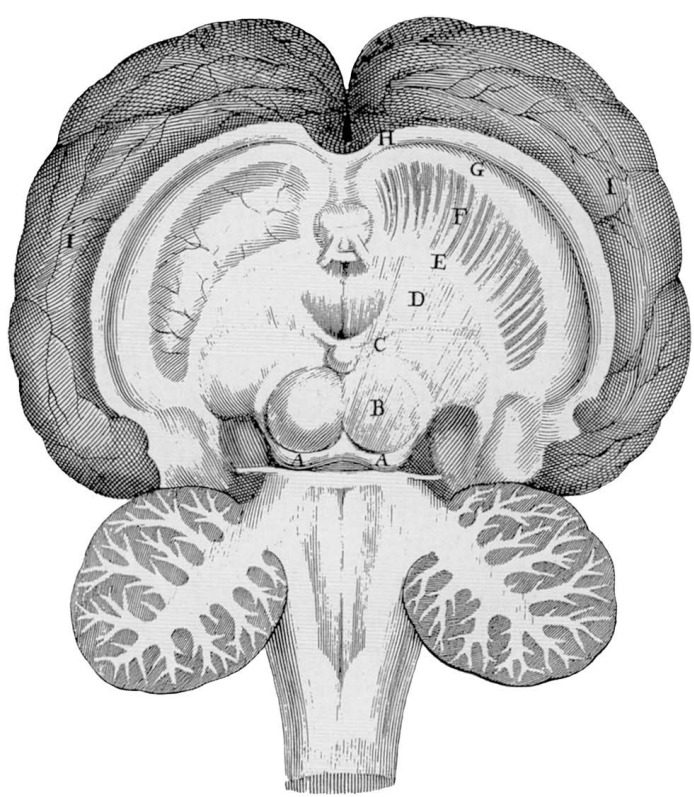

Figure 2. Thomas Willis's drawing of a horizontal section of the human brain in which the detailed rendering of the corpus striatum contrasts with the rather sketchy depiction of the cerebral convolutions [6].

(a)

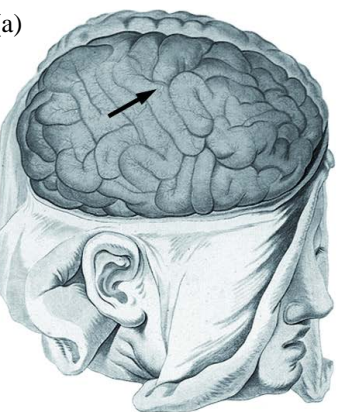

(b)

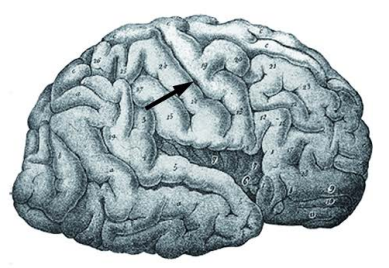

(c)

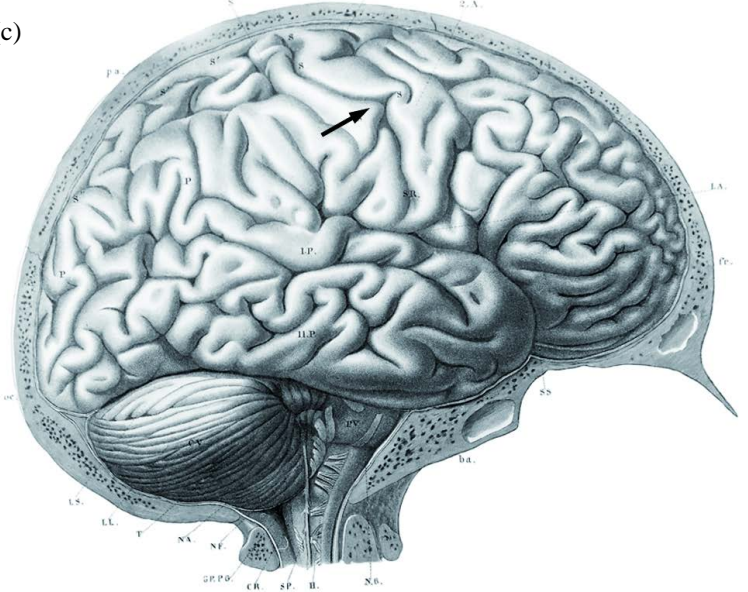

Figure 3. Lateral views of the cortical surface of the human brain, such as depicted by: (a) Vicq d’Azyr [8]; (b) Rolando [10]; and (c) Leuret and Gratiolet [13]. Arrows have been added to the original drawings to facilitate the identification of the central sulcus. 
axis (axon), whose distal segment is enshrouded with a myelin sheath (Figure 4(a)). More questionable are other illustrations depicting anastomoses that were thought to link neurons with one another, in accordance with the then widely held reticularist view of the organization of the central nervous system (Figure 4(b)). In collaboration with Leuret, Gratiolet provided detailed descriptions of the brains of various mammals, including a beautiful rendering of the encephalon of an elephant (Figure 4(c)). However, much of his interest was oriented towards primates. In regards to the human brain, Gratiolet was the first to accurately describe the various groups of subcortical fibers, including the association, commissural and projection systems. He also depicted the fibers that emerge from the lateral geniculate body and arborize within the visual cortex, the geniculocalcarine tract, which is still known today as Gratiolet's optic radiation [11].

Gratiolet took advantage of the rich collections of the Muséum d'histoire naturelle to initiate a long and painstaking study in which he compared the organization of the human brain with that of several lesser and greater apes and of 20 different species of New World and Old World monkeys. The results of this unique investigation were summarized in a remarkable treatise entitled Mémoire sur les plis cérébraux de l'homme et des primates published in 1854 [12]. An extended version of this work appeared in 1857 in the second volume of Leuret's book [13].

In the middle of the $19^{\text {th }}$ century, neurologists commonly separated the human brain along the antero-posterior axis into an anterior and a posterior lobe. Instead, Gratiolet subdivided the human cerebral hemispheres into five distinct lobes that he named according to the portion of the skull that covered each one of them. He considered the insula as a central lobe around which revolved the frontal, parietal, occipital and temporal (temporo-sphenoidal) lobes. He correctly identified most gyri and sulci on all brain surfaces and introduced the term plis de passage for some interconnecting gyri.

His detailed comparative study of the primate brain led him to realize that the organizational pattern of the cerebral convolutions was highly predictable in all primates, up to the point that it could serve as a criterion to classify the various primate groups. He noted that only the deepest sulci exist in lower primate forms, while the number and complexity of cortical folds increase markedly in great apes and humans (Figure 5). Gratiolet was also the first to notice a fundamental difference between apes and humans in regards to brain development. Whereas sulci appear first in the posterior part of the cerebral hemispheres in apes, they become first visible in
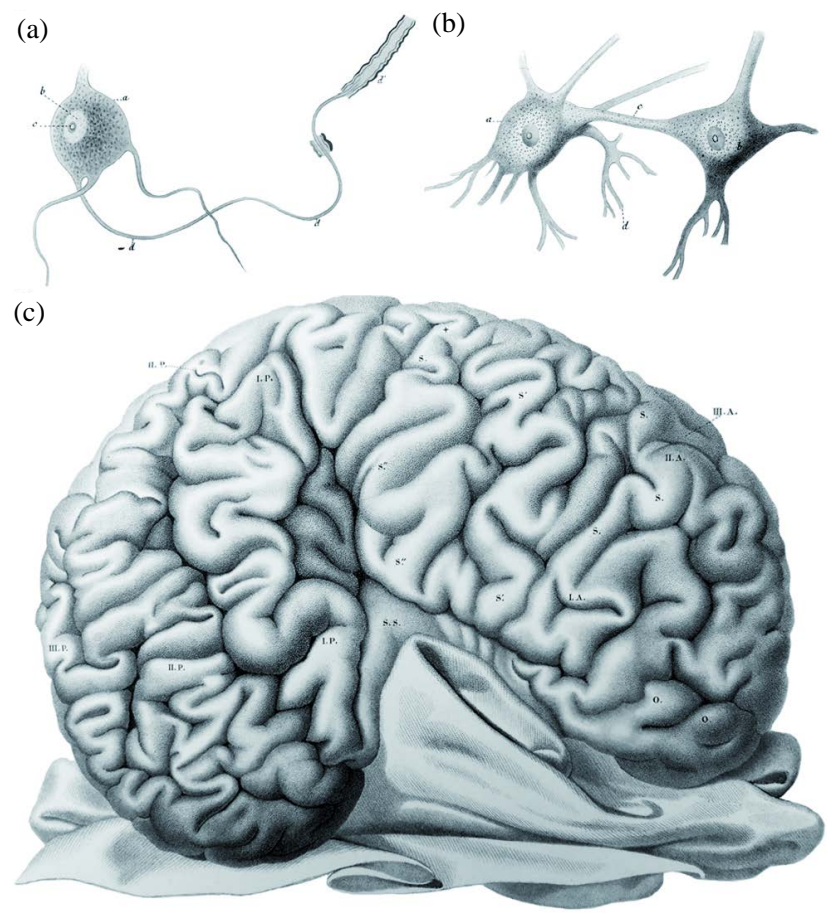

Figure 4. Gratiolet's microscopic depiction of ((a), (b)) neurons in the human spinal cord, and (c) a macroscopic view of the lateral surface of an elephant brain [13]. 


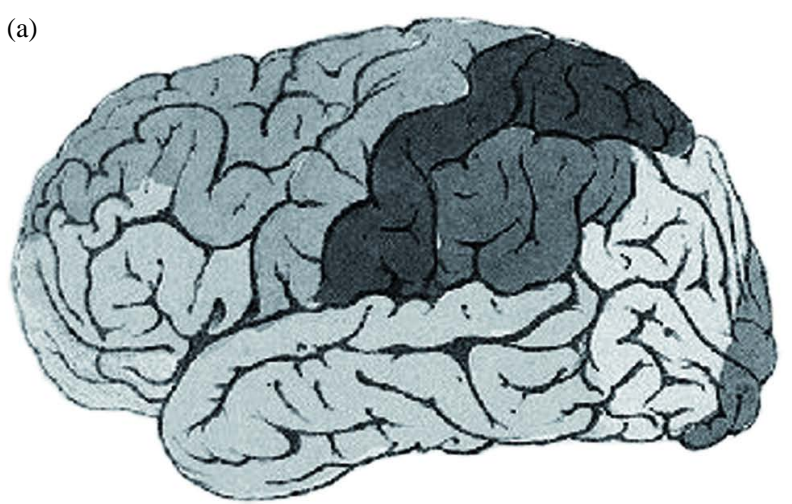

(b)

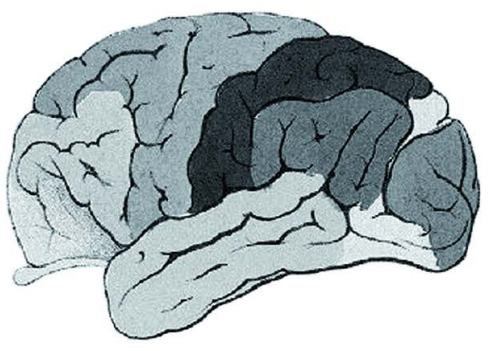

(c)

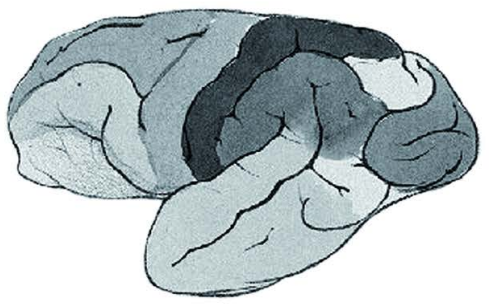

(d)

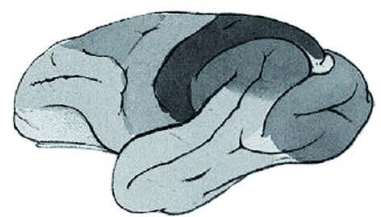

Figure 5. Gratiolet's comparison of a lateral view of the brain of: (a) a modern man (Homo sapiens sapiens); (b) an orangutan (Pongo pygmeus, a great ape); (c) a gibbon (Hylobates leusciscus, a lesser ape); and (d) a langur (Semnopithecus entellus, an Old World monkey) [12]. Here, Gratiolet disregarded the relative proportion of the brains to better illustrate the gyri and sulci in each species.

the frontal lobes in human fetus. Several leading authorities from various European countries, including the celebrated English geologist and evolutionist Charles Lyell (1797-1875), greatly valued Gratiolet's contribution to our knowledge of primate brain organization. Lyell considered Gratiolet "the highest authority of our age on brain anatomy" and he went as far as to borrow some of Gratiolet's drawings for his own work of human evolution [14].

\section{About Human Brain Function and Races}

Surprisingly, the $19^{\text {th }}$ century neuroanatomist who subdivided the human brain into such a large number of distinct entities did not paid much attention to the functional significance of this remarkable diversity. Gratiolet adopted the prevailing unitary view of brain function: "Generally speaking, I agree with Flourens [the French 
physiologist Marie-Jean-Pierre Flourens (1794-1867)] that intelligence is unitary, that the brain is one and that it acts above all as an integral organ [organe d'ensemble]" [13]. He held this position largely because of the lack of hard data confirming any particular case of functional localization. However, he finally accepted the demonstration by his colleague and fellow citizen Paul Broca of a language center located in the inferior frontal gyrus, a convolution that he had himself so clearly delineated (pli surcillier).

The issue of the relationship between brain size and intelligence was hotly debated during the sessions of the Anthropology Society that were held in Paris early in 1861. Gratiolet took an active part in that debate headed by Broca, who affirmed: "In general, the brain is larger in men than in women, in eminent men than in men of mediocre talent, in superior races than in inferior races” [15]. Gratiolet strongly opposed Broca's view of a direct relationship between intelligence and brain size. He thought that, either in individuals or in races, the volume of the brain was relatively meaningless. He believed that, in the search for anatomical correlates of human intelligence, a detailed analysis of the shape and internal organization of the brain was likely to be much more rewarding than measuring the total cerebral mass.

However, Gratiolet adhered largely to Broca's ideas about the influence of races on brain conformation. For Gratiolet, inferior races were no degraded Caucasians but perfect beings that were simply placed lower on the scale of creation, a condition that reflected itself upon brain organization. To illustrate his point, Gratiolet compared the brain of a typical white European male to that of Saartjie ("Sarah") Baartman (ca.1789-1815), a young South African slave best known as the Hottentot Venus. Baartman, who displayed steatopygia (fat bottoms) and macronymphia (hypertrophied labia minora), which are typical genetic traits of her ethnic group (Khoisans), was brought to London and Paris to be exhibited as a symbol of black inferiority and hyper sexuality. She died in Paris probably of pneumonia, at about 25. During Baartman's autopsy, her brain (as well as her genitals) was dissected out and kept on display at the Muséum d'histoire naturelle, where Gratiolet had ample time to study it. He depicted Baartman's brain as being much less convoluted than that of a white male (Figure 6) and compared

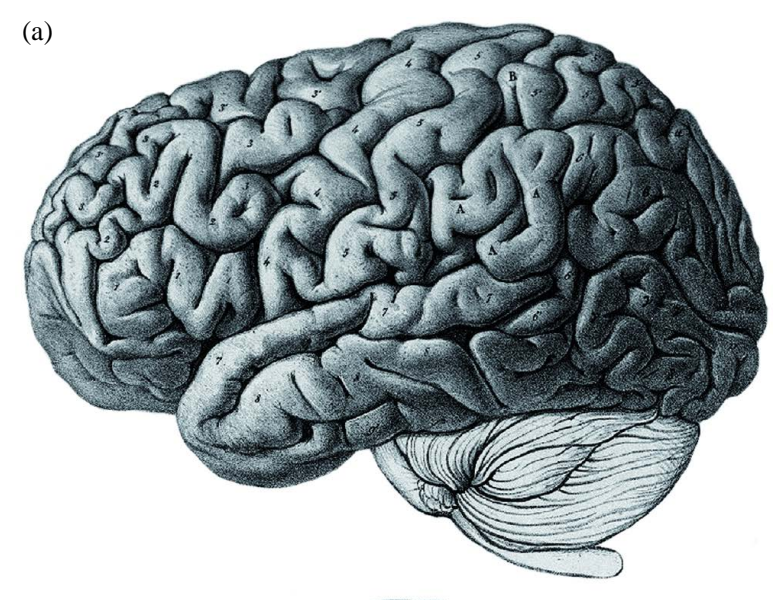

(b)

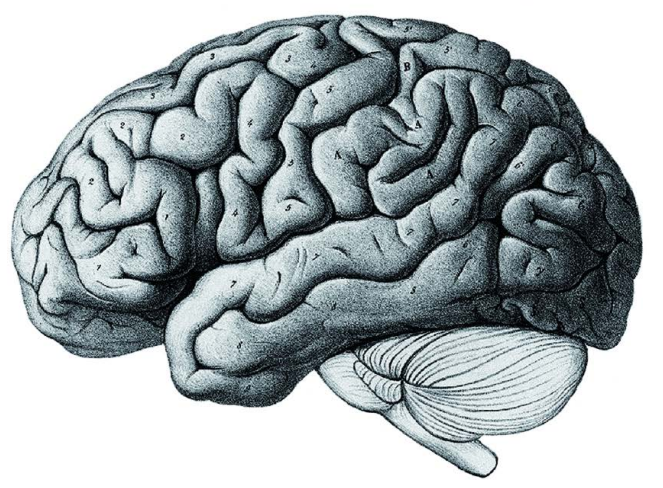

Figure 6. Gratiolet's comparison of a lateral view of (a) the brain of a white European male with (b) the brain of Saartjie Baartman (nicknamed the Hottentot Venus) [12]. The brains were not drawn at the same scale. 
it to the brain of an idiot [12]. Since Baartman had been previously interviewed by his former mentor de Blainville, as well as by the celebrated French zoologist Georges Cuvier (1769-1832), Gratiolet knew that she was an intelligent person. Taking that into account, he concluded that what is perfect for inferior races is imperfect for superior ones or, in other words, what is inferiority is some races is degradation in others.

Such harsh statements reveal that Gratiolet shared with most $19^{\text {th }}$ century neurologists a genuine racist view of brain organization. Yet, despite his unfortunate incursion in the mined-field of interracial comparisons, Gratiolet deserves our full respect for having provided us with the first clear and detailed views of the organization of the brain surface in a large number of primates, including man. The various brain maps that he so meticulously constructed are still guiding neuroscientists at work today.

\section{References}

[1] Parent, A. (1996) Carpenter’s Human Neuroanatomy. 9th Edition, Williams \& Wilkins, Baltimore.

[2] Colonnier, M. (1981) The Organization of the Cerebral Cortex. MIT Press, Cambridge, 125-152.

[3] Broca, P. (1865) Éloge funèbre de Pierre Gratiolet prononcé sur sa tombe le 16 fevrier 1865. E. Martinet, Paris.

[4] Parent, A. (2009) Histoire du cerveau. De l’antiquité aux neurosciences. Les Presses de l’Université Laval, Québec \& Chronique Sociale, Lyon.

[5] Sylvius, F. (1663) Disputationes medicarum. J. van den Bergh, Amstelodami.

[6] Willis, T. (1672) De anima brutorum. R. Davis, Oxonii.

[7] Parent, A. (2012) The History of the Basal Ganglia: The Contribution of Karl Friedrich Burdach. Neuroscience \& Medicine, 3, 374-379. http://dx.doi.org/10.4236/nm.2012.34046

[8] Vicq d’Azyr, F. (1786) Traité d'anatomie et de physiologie. Didot, Paris.

[9] Gall, F.J. and Spurzheim, J.K. (1810-1819) Anatomie et physiologie du système nerveux en général et du cerveau en particulier (4 vol.). E. Schoell, Paris.

[10] Rolando, L. (1829) Della struttura degli emisferi cerebrali. Memorie della Regia Academia delle Scienze di Torino, 35, 103-145.

[11] Gratiolet, P. (1854) Note sur les expansions des racines cérébrales du nerf optique et sur leur terminaison dans une region determinée de l'écorce des hémisphères. Comptes Rendus des Séances de l'Académie des Sciences (Paris), 39, 274-278.

[12] Gratiolet, P. (1854) Mémoire sur les plis cérébraux de l’homme et des primates. A. Bertrand, Paris.

[13] Leuret, F. and Gratiolet, P. (1839, 1957) Anatomie comparée du système nerveux consideré dans ses rapports avec l’intelligence. Baillière, Paris, Vol. 1 (F. Leuret), Vol. 2 (P. Gratiolet), 1857.

[14] Lyell, C. (1863) Geological Evidences of the Antiquity of Man. J. Murrray, London.

[15] Broca, P. (1861) Sur le volume et la forme du cerveau suivant les individus et les races. Bulletin de la Société d'Anthropologie (Paris), 2, 139-204, 301-321, 441-446. 